Tér és Társadalom 23. évf. 2009/3. 63-77. p.

\title{
MOBILIZÁCIÓ: AZ UTAZÁSI ÉLETÚT VIZSGÁLATÁHOZ
}

\author{
(Mobilization: Analysis of Mobility Biographies)
}

\author{
MAYER PÉTER
}

Kulcsszavak:

mobilitás életút utazási szokások

Jelen tanulmány az utazási szokásokat a tágabb mobilitási élettörténettel és a jelenlegi gyakorlattal összefüggésben vizsgálja. A mobilitási életút kvalitativ vizsgálata alapján három olyan ideáltípust mutat be, amelyek a mobilitás fejlödésének eltérö módjait reprezentálják. A mobilizáció fogalmának megragadásával egyrészt a mobilitási dimenziók közötti kölcsönhatás, másrészt a mobilitás fejlödésének változása áll a középpontban. A cikk továbbá rávilágit arra, hogy a turisztikai magatartás korántsem magyarázható pusztán az egyéni utazó fogyasztói döntéseivel, abban a társadalmi kapcsolatrendszernek és az egyén intézményi beágyazottságának is jelentös szerepe van.

\section{Elméleti keretek}

Tér

A tér fogalmával kapcsolatosan két paradigma áll szemben egymással. Az abszolút térfelfogás a teret egy önálló sajátosságokkal rendelkezö entitásnak tekinti, mely a benne található dolgok számosságától és tulajdonságaitól fưggetlenül létezik és objektiven megfigyelhetó. Ezzel ellentétben a relativ térfelfogás értelmében a teret csak a dolgok (emberek, tárgyak) pillanatnyi konstellációja határozza meg. Jellemzően a tér abszolút jellegét feltételező gondolkodók a relatív teret az abszolút tér egy konkrét részének tekintik. Itt tehát a relativ tér az abszolút térnek logikailag alárendelt entitás, mely örökli, és kézzelfoghatóvá teszi az abszolút tér sajátosságait. Alapvetően eltér ettől a tér relatív elméleteinek felfogása, melyek közös pontja a tér abszolút jellegének tagadása. A tér ebben a felfogásban, mint az együttlétezés egy adott rendje, mintája adott: a helyeket elfoglaló dolgok e relatív térfelfogás szerint a köztük levő viszony révén alkotnak teret (Löw 2001). E viszony jellegére vonatkozóan három megközelítés létezik. Az első szerint a térbeni viszonyok az euklidészi geometria szerint rendeződỏ természeti adottságokon (nyersanyaglelöhelyek, közlekedésre alkalmas domborzati és vízrajzi viszonyok stb.) alapulnak. Másrészt, Leibnitz szerint a rendező viszony eredete a kultúrában rejlik, vagyis a térbeni viszonyok nem a természet puszta létéböl, hanem annak használati módjából adódnak. E felfogás alapján a tér (és ennek egy elemeként: a természet) az ember által alakítható, mivel a cselekvések egymáshoz füzódó viszonya adja meg a tér jellegét és kiterjedését is. E felfogás alapján a teret a helyek között viszonyokat te- 
remtő társadalom határozza meg tevékenységei, cselekvései révén. Harmadik megközelítésként Kant szerint a tér nem objektív anyagi-fizikai, vagy a cselekvés által meghatározott viszonyrendszer, hanem ideológiai-szellemi fogalom, a külvilág érzékelési sémája. Szerinte mindenfajta térhasználatot megelőz és meghatároz a teret alkotó dolgokról a cselekvőben kialakult felfogás. A kanti felfogás szerint tehát értelmezési rendszerünk alapján helyezzük el az érzékelt dolgokat térben és időben. Utóbbi két felfogásból az következik, hogy egyazon természeti térben különbözỏ emberek vagy társadalmi csoportok eltérő cselekvési tereket érzékelnek, illetve alakítanak ki (Mayer-Pénzes 2007).

\section{Mobilitás}

A társadalomtudományokban a mobilitás két megközelítésben jelentkezik. Egyfelöl fizikai, térbeli mozgást, másfelöl a társadalmi státuszban bekövetkezett változást jelent. Míg a térbeli mobilitás a tudományok munkamegosztási rendszerében elsősorban a földrajztudományokban vált dominánssá, a társadalmi mobilitás a szociológiai elemzések felségterülete lett. A nyolcvanas években ez a határvonal a kettős törekvéseknek köszönhetően kezdett összemosódni, és megkezdődött az elméletek integrálása és a közös tudományos diskurzusok kialakítása. Ez érintette az életteret, helyszíneket, lokalitásokat, mint kulturális és társadalmi kategóriákat (GregoryUrry 1985). Ahogyan Lash és Urry (1994) rámutattak, a mobilitásnak abban is szerepe lesz, hogy az egyének hogyan értelmezik a világot. A mobilitás más típusai mellett a turizmus a másság megtapasztalásának élményét biztosította - kezdetben a kiválasztott kevesek (Towner 1985), majd a 19. századtól kezdve a tömegek számára is (elöször Angliában, majd a 20. század folyamán a fejlett társadalmakban mindenhol). Ez elsősorban a technológia fejlödésének és számos jogszabályi, társadalmi és szervezeti intézkedésnek köszönhető, mint például a szabadsághoz való jog, növekvő hatékonyság a munkában, a szabadidős tevékenységek intézményesülése. Az utazás során - akár szabadidős, akár üzleti céllal történik - szándékolt és nem szándékolt formában kulturális csere megy végbe. Ez a tényleges interkulturális verbális kommunikáció mellett a megszokottól eltérö mindennapi élethelyzetek megfigyelésének és azok megoldására kialakított intézményesült megoldások megtapasztalásának az eredménye. A mobilitás és ezen belül a turizmus ezért mindig is hozzájárult a hétköznapi élet relativizálódásához és kozmopolitává válásához (Beck 2004).

Általánosabb szinten nézve, a mobilitás és kifejezetten a turizmus nyomán a hétköznapi életben zajló változások és választások növekvö elfogadottságát az individualizáció elméleti keretébe helyezi a témával foglalkozó szakirodalom. Az individualizáció a modernizáció egyik aspektusa, mely szerint ,az egyén a legfőbb referenciapont lesz mind a társadalom, mind saját maga számára" (Junge 2002, 7). Ebben az összefüggésben az egyénileg kiválasztott és felépített életvitel ("Lebensführung") a növekvő mobilitási szint nyomán az egyénre nehezedő piaci kihívásokra adott válaszként funkcionál. Ezt jól reprezentálja a társadalmi valóság érzékeltetésére alkalmazott metaforák változása: a homogén csoportokból álló, hierarchikus társa- 
dalmi struktúrából egy képlékenyebb és heterogénebb hálózat-típusú társadalmi rendszerbe való átmenetet. Ennek során a társadalmi kapcsolatok háromféleképpen individualizálódnak: társadalmi, időbeli és életrajzi, valamint térbeni viszonylatban (Appadurai 1990; Albrow 1996; Urry 2000; Keupp et al. 2001).

A térbeli mobilitásban Bonß és Kesselring (2001), a „lehetőségek terét” szélesítő és alakító eszközt lát. A mobilitás itt a homogén és stabil kapcsolatok felbomlásának folyamataként jelenik meg azáltal, hogy kibontakoztatja az individualizáció emancipatív aspektusát (Beck 1986) - együttesen a tér és a társadalom dimenzióiban. A térbeli (de nem szükségszerüen testi) és a társadalmi mobilitás tehát egyszerre, öszszekapcsolódva van jelen. A térbeni mobilitást Kaufmann (2004) két komponensre, a térbeli mozgásra és a motilitásra bontja. Analitikusan nézve a mozgás oka mind az egyéni aspirációkra (motilitásban), mind a társadalmi nyomásra és kényszerekre visszavezethető. A mobilitás a térbeli mozgásnak csak egyik, a motilitás eredményeként létrejövő típusa. Mobilitásról így akkor beszélünk, ha a mozgás célja a motilitási potenciál megvalósulása, ha az a választható terek és ezzel a döntési alternatívák bővítésének eszköze. A térbeli mozgás másik típusa az egyén kontextusából következő mozgás, amely a strukturális változások individualizálódó hatásának eredménye (Beck 1986). Az empirikus kutatási adatok alapján a mobilitás egyfelől magában foglalja a virtuális mobilitást, pl. az új technológiák használatával megvalósuló „telejelenlétet” (Vogl 2005), másfelöl a mobilitási infrastruktúra új használatát - mind egyéni, mind intézményi szinten.

Kaufmann (2004) az egyéni mobilitási stratégiákat elemzi az interakciók, struktúrák és kontextusok szempontjából. Három tényezőt azonosít, amelyek meghatározzák az egyének mobilitási szintjét és mintáját. Ezek közül az első a hozzáférés a mobilitási „terekhez” (ide értve a lehetőségeket meghatározó közlekedési- és kommunikációs infrastruktúrát). Ez mind a fizikai rendelkezésre állást, mind pedig a társadalmi-gazdasági hozzáférést (mint például árszint, idópont) tartalmazza. A kompetencia azokra a képességekre, készségekre utal, amelyek a hozzáférhetö mobilitási terek használatához szükségesek ('igy pl. menetrendek használata, foglalási módok ismerete). Harmadik tényező a megfelelés, amely tartalmaz minden olyan viselkedési elemet, amely a mobillá váláshoz szükséges, pl. a terek használatának igényét és hajlandóságát. Fontos kiemelni ezeknek az egyéni cselekvéseknek és interakcióknak, valamint az ezekhez kapcsolódó mobilitásoknak az intézményesülési tendenciáit. A hétköznapi élet növekvő mobilitása lehetővé teszi a Pries által (1998) a migráció vonatkozásában bevezetett „pluri-lokális” életforma-fogalom átértelmezett, szélesebb körü használatát. A Pries-i migráns kettős társadalmikulturális beilleszkedését (amely a kirekesztés/integráció fogalmait relativizálja) általánosíthatjuk ezzel a társadalmi-földrajzi terek használati módjainak kontinuumára. Pluri-lokális életformaként tehát az emberekhez és tárgyakhoz való kötődés különböző szintjeit és mintáit azonosithatjuk. Ezzel a fogalommal ragadhatjuk meg a társadalmi és a földrajzi tér különválásának jelenségét, a társadalmi és a földrajzi távolság függetlenedését egymástól (Appadurai 1990). 


\section{Az életút és az utazási szokások időbeni változása}

Az életút, mint társadalmi konstrukció a késő modernitásban jelentős változásokon ment keresztül. Kohli (1989) a modern társadalmakban az életút intézményesülését a „normál életút” fogalommal ragadja meg. Ez a munka köré szerveződve három, egymástól markánsan elkülönülő fỏ szakaszra tagolható. Az első a felkészülés időszaka, vagyis a gyerek- és fiatalkor munkavégzés előtti időszaka. A második szakasz a formális munkavégzés, vagyis a jogi és munkaerö-piaci intézményekkel körülbástyázott alkalmazotti státusz időszaka. Az első és a második korszak közötti átmenetet egyebek között az iskolai végzettség megszerzése, az első munkába állás és a jogi értelemben vett nagykorúság mérföldkövei jelezték. A harmadik szakasz a nyugdijas évek munka utáni időszaka. Ennek elérését a nyugdijba vonulás, a biológiai öregedés és az időskori intézményekbe (pl. nyugdíjas szervezetekbe) való bekapcsolódás jelezték. Kohli és mások (Kohli 1989; Osterland 1990) a normál életutat mindig is elméleti konstrukciónak tekintették, amely mögött réteg- és nem-specifikus empirikus változatok sokasága áll. Egy átfogó változás azonban megfigyelhetö az utóbbi két évtizedben: az életút egyértelmü irányultsága, vagyis a normál életút karrierként, fejlődésként való megragadása mind kevésbé állja meg a helyét.

A turisták utazás alatti viselkedésének vizsgálata a turizmussal foglalkozó szakirodalom egyik központi témája. Ennek ellenére is elenyésző azon kutatások aránya, amelyek e magatartás-együttest egységes dinamikus keretben, a turista életútja során bekövetkező változásokat középpontba állítva vizsgálják. A szabadidő-kutatásban Rapoport R. és Rapoport R.N. (1975) mutatott rá a családi életciklus alapján történő vizsgálat fontosságára. Az elmélet gyakorlati alkalmazhatóságát mindazonáltal behatárolja a tradicionális családmodell és életút felbomlása és individualizálódása (Zimmermann 1982; Bojanic 1992; Opperman 1995). A turista-viselkedés dinamikáját más oldalról közelítik meg a „turista karrier-létra” elemzések (Pearce 1982; 1988; Ryan 1998; Correira et al. 2007). Pearce ebben átveszi Maslow-tól a szükségletek hierarchizált felfogását, valamint magát az öt szükségleti szintet is, bár magukat a szükségleteket valamelyest módosított formában alkalmazza. Pearce modellje a jelenlegi turisztikai viselkedés magyarázatát a múltbeli utazási tapasztalatokkal kapcsolja össze. Ezt egyben fejlődésként mutatja be, amikor az összeadódó utazási tapasztalatok nyomán egyértelmüen magasabb szintü szükségletek kielégítésének igényét látja a változó utazási szokásokban (Pearce 1982; 1988). Az utazási létra modell így az utazási szokások változásának irányultságát feltételezi, hiszen - az egyéni belépési szintek ellenére is - intézményesült előrehaladási mechanizmust ábrázol.

\section{Módszertan}

A tanulmány alapjául szolgáló kutatás a mobilitás különböző dimenzióinak hatását vizsgálja a hétköznapi életre. A hétköznapi mobilitás, a migráció és a turizmus dimenzióiban és az életút folyamatában vizsgált mobilitást ennek során társadalmi- 
kulturális konstrukciónak tekintettük, vagyis tartalmukat, kiterjedésüket és a köztük húzódó határokat a vizsgálati alanyok értelmezésétöl tettük fuiggővé.

A kutatás során három szinten szembesültünk kiválasztási problémával. Elsőként a kutatás tematikus kiterjedését kellett lehatárolni. A mobilitási dimenziókat és a mobilitást befolyásoló tényezőket a térbeni mobilitás szociológiai irodalma alapján határoltuk le az elméleti kereteknél meghatározott témakörökre és fogalmakra. A második döntés a kutatás idöbeli dimenziójára vonatkozott. Itt a három lehetséges megközelítésmód (egyszeri, összehasonlító és életrajzi megközelítés) közül az öszszehasonlító elemzés nem volt lehetséges, mivel ebben a témakörben nem csak a jelenlegi vizsgálat alanyairól nem állt rendelkezésre panel jelleggel felhasználható korábbi információ, de általánosabb, trend jellegü összehasonlításra alkalmas korábbi kutatási eredmény sem volt fellelhető. Az egyszeri adatfelvételre épülő vizsgálatot a kutatás megcélzottan dinamikus jellege zárta ki. A fennmaradó életrajzi megközelítés - számolva az emlékezés korlátaiból adódó torzításokkal - ígéretes perspektívát nyújtott. A kutatás alanyainak kiválasztásában a kvalitatív kutatási módszernek megfelelően a változatosság volt az elsödleges szempont. Elsőként olyan élethelyzeteket kerestünk, amelyekben a várakozások szerint a mobilitásnak a legkisebb a szerepe. Ennek megfelelően a kiinduláskor rurális környezetben élö és idős válaszadókat kerestünk. A későbbiekben ezt a kört tágítottuk úgy, hogy vidék-város, férfi-nő, fiatal-idős és felsősokú-nem felsőfokú végzettségü dimenziókban változatos mintát kapjunk. A kutatás során összesen 20 személlyel készült mélyinterjú, ami öszszesen 137 életszakaszban, illetve a köztük levö átmenetben tette lehetóvé a mobilitás három dimenziós vizsgálatát. $\mathrm{Az}$ interjúk három részböl álltak: egy narratív életútinterjúból, egy-egy probléma-orienált mobilitás-történeti és turizmus-történeti részböl. Utóbbiak a narratív interjú alapján le határolt életszakaszokban vizsgálták a hétköznapi mobilitást és a turizmust. A kapott információk értelmezése az Atlas.ti kvalitatív elemző szoftver felhasználásával történt, a kódlistát nyitott és in vivo módszerrel állítottuk elỏ. Az életút és az életszakaszok mobilitási és kapcsolathálózati információit a további elemzéshez sematikus térképek segítségével jelenítettük meg.

\section{Mobilitási ideáltipusok}

\section{Beágyazott}

P.M. 69 éves nyugdíjas gyári munkás, aki jelenleg is szülőfalujában lakik az ipari központ várostól $8 \mathrm{~km}$-re. Jelenlegi mobilitási mintájára a hétköznapi és a turisztikai mobilitás éles térbeni elkülönülése a jellemző.

A hétköznapokban mobilitása legnagyobb része a megszokott környezeteként megélt faluján belüli mozgás, ahol napi rendszerességgel mozog lakóháza és a szölöje között. Ehhez legalább heti gyakorisággal a presszó, az unoka általános iskolája, a templom és a kóruspróbáknak helyet adó kultúrház társulnak. A tágabb környezetet tekinti erőforrásokat biztosító otthonának: a szőlők, az erdők, a gombászás vissza- 
térően megjelenő fogalmak. A mobilitás célja a falun belül a társadalmi kapcsolatok ápolása. A megszokott környezet teréböl való kilépés valamilyen feladat elvégzéséhez kapcsolódik: orvoshoz vagy bevásárolni kell a közeli városba beutazni. Hétköznapi mobilitási mintája egy állandó időstruktúrába ágyazódik be, amely a munkahely külső kényszere nélkül is meghatározza a térhasználati minták elrendezését. A mobilitást a tradíciók által meghatározott napi rutin vezérli, a döntési helyzetek ritkák, az információszükséglet elenyésző.

Jelenlegi turisztikai célú utazásait két csoportba oszthatjuk. Rendszeresen részt vesz feleségével és szomszédaival, illetve barátaival egynapos szervezett termékbemutatókon, ahol a kötelező programon (a bemutatón) kívül ellátást is kapnak, és lehetôség nyílik a bemutató helyszínének megismerésére. Az utazások másik típusa kórusbeli tagságához kapcsolódik: havi rendszerességgel járnak elsősorban környékbeli helyekre fellépésekre, illetve kétszer a falu testvértelepülésére Ausztriába. A meglátogatott helyek többségében újak, a visszatérés eleme hiányzik. Az utazások célpontjai nem bővítik az általa tudatosan megélt teret. Az utazások során szerzett élmények nem hatnak a hétköznapokra, a látottak érdekesek, de idegenek maradnak, valamint az utazás során sem lép ki hazai társadalmi kömyezetéből. Az útitársakkal közös tevékenységek az otthoni életböl származnak: a beszélgetések témái, a tréfák, az iszogatás.

A mobilitási életutat vizsgálva az látható, hogy az időre és térre vonatkozó képzetek rendkivuül nagy stabilitást mutatnak. Az otthonként megélt térnek sem a kiterjedésében, sem pedig a szerkezetében nincsen változás, pedig elköltözik egyszer a falun belül egy újonnan épülő utcába, hasonlóan más fiatalokhoz. Az együttes költözés miatt a társadalmi tér nem változik, a kapcsolatok és a szerepek pontosan úgy élnek tovább az új helyen, mint korábban.

Az ipari munkahelyre ingázás évtizedeiben a mobilitási mintája lényegesen változik: új hely jelenik meg a térképen, a városi gyár, amely csak egy hely marad, és nem válik a teret alakító tényezôvé, nem bír jelentéssel. A társadalmi tér értelmében a gyár nagyszámú kapcsolatot jelent, de ezek nem erősödnek meg, mélyebb szolidaritásról csak a falubeli munkatársai esetében számol be. Mégis a gyár révén jelenik meg a turizmus az életében. Turisztikai életútjában a támogatott szociálturizmusnak kiemelkedő szerepe van. A gyárban kapott beutalókkal jut el nyaralni családjával az országon belül, illetve volt szocialista országokba. Nem kéri, nem kezdeményezi és nem is szervezi ezeket az utakat, nem nyaralni megy, hanem nyaralni küldik. E nyaralásokon kívül rokonlátogatások fordulnak elö, amelyek évente egy-kétszer, kizárólag a meglátogatott személyekkel való kapcsolattartásra korlátozódnak. Rendkívüli eseményként még egy, 100 km-re levő kórházban kapott kezelés fordul elő.

A mobilitás szervezésében élete legnagyobb részében a közösségi megoldások és minták jellemzőek. A közlekedési módok közül a tömegközlekedésé a föszerep, nincs olyan utazási igénye, amely ilyen módon ne lenne kielégíthetö. A turizmus terén egy időben használ saját autót, de ennek szerepe soha nem jelentős életében, nyugdíjba vonulása után a kocsit eladja. A személyes mobilitás e szimbólumának csekély jelentősége jól jellemzi mobilitással kapcsolatos attitüdjét: nem törekszik 
annak bövítésére, tökéletesen megfelel számára a megszokott, tradicionális környezeten belüli mozgás. Követi azokat a mintákat, amelyek szükebb társadalmi környezetét jellemzik, így a mobilitás nem gyengíti, hanem erősíti társadalmi beágyazottságát. P.M. számára a térnek egyértelmü határai vannak, és ezek a határok tapasztalata szerint nem változnak. Mobilitása így a megszokott környezet rendelkezésre álló terét kitölti, de nem alakítja. A tér- és időhasználatra vonatkozó attitüdjei mögött a tradicionalitás olyan alapvetö mintái húzódnak meg, amelyekre a modernizációs hatások (saját házba költözés, ipari munkahely) sem voltak lényegi hatással. Turisztikai mobilitása sem az individualizáció, hanem éppen az erős társadalmi beágyazottság következménye: mobilitási mintáját a földrajzi térben való mozgás mellett a társadalmi tér állandósága jellemzi.

\section{Kontingens}

H.A. 28 éves értékesítő, elvált, két gyermekkel, jelenleg szülöfalujában lakik, bár élete során többször elköltözött onnan. Hétköznapi mobilitásában a magánéletszabadidő és a munka életszférái két, térben markánsan elkülönülő szegmenst alkotnak. A magánélethez kapcsolódó mobilitása falujához, illetve a közeli kisvárosra terjed ki. Napi rendszerességgel szülei, testvére háza, a gyerekek iskolája a felkeresett helyek, melyekhez heti vagy annál nagyobb gyakorisággal a közelben lakó barátainak otthonai, az egyik falubeli presszó (ahol a barátokkal találkozik) és a városi üzletek adódnak. Távoli barátaival a mobilitás minden formáját alkalmazza a kapcsolatháló fenntartása érdekében: Internet, mobiltelefon, személyes találkozások. Beszámolóiban otthonként mindig csak a szülői házra utal. A lakóhelyen kívüli mozgást lehetőségteremtésnek tekinti, amely felszabadítja az otthon kötöttségei alól. A jelenlegi turisztikai célú utazások az ő esetében is két csoportba oszthatók. Egyrészt nagy fontosságot tulajdonít az éves családi nyaralásnak, amelyet anyagi lehetőségei függvényében tágabb családjával - szüleivel, testvére családjával - külföldön töltenek el. Emellett rövidebb barát- és rokonlátogatások, illetve a velük harmadik helyszínre tett néhány napos utak évente többször is elöfordulnak.

Az élettörténet egészének mobilitására a változatosság jellemző. Rövid, néhány hónapos időszakokra többször költözik el otthonról, de ezek mögött mindig valamilyen kényszer húzódik meg (középiskola, a szülői ház átmeneti foglaltsága, munkanélküliség, új kapcsolat). A gyermekkorban megszokott szabadság későbbi életszakaszainak mobilitásában már tudatosan van jelen. Míg a gyermekkori barangolások a tér egészét állandónak, bejárhatónak és adottnak tekintik, addig otthonról való első elkerülése, a hazajárás, majd az újbóli hazakerülés után az eljárás kialakítja benne a múlandóság érzését. A helyek munkatapasztalatok és jövőbeni munkalehetőségek, szerelmekkel, barátokkal, üzleti partnerekkel folytatott interakciók reprezentációiként jelennek meg. A tér csak, mint leküzdendő távolság jelenik meg, amely a kapcsolattartást és így az életvitelt költségessé teszi. Térhasználatában a szelektivitás lesz jellemző: a tudatos választások és a spontán események kiemelnek és jelentéssel töltenek meg bizonyos helyeket, a köztük levö tér azonban nem válik 
fontossá. A térrel kapcsolatos, látszólag ellentétes attitüdjeit (lehetőség vs. akadály) egyrészt az idôhöz való viszonya oldja fel (minden állapotot átmenetinek tekint, nem hisz az állandóságban, jövőbeli stratégiáit a változásra való felkészülés, a lehetőségek nyitva tartása határozza meg). Másrészt a mobilitás különböző formáit is az egyensúlyozásra használja ki: a jobb munka érdekében elköltözik, de hazajár, hogy barátságait ápolja, majd hazaköltözik, és üzleti utakra jár el.

Ebbe a folyamatos változatosság- és egyensúlykeresésbe illeszkedik turisztikai élettörténete is. Az utazás a család életében normális tevékenység, az éves nyaralásokon kívül rendszeresek a rövidebb saját szervezésủ hétvégi kirándulások. A szervezett, programokban gazdag családi nyaralások mellett a gyerekkor visszatéró programja a balatoni iskolai tábor. A középiskolás évektöl kezdve osztálytársakkal, barátokkal utazik, saját szervezésben, kötetlenül (kempinges nyaralás, rövid kirándulások a jellemzőek). Az iskola nem az érettségi társadalmilag meghatározott mérföldkövével zárul, terhessége lendíti át egy új életszakaszba és egy más kapcsolatrendszerbe. Ebben az utazást első gyerekének születése egy idöre háttérbe szorítja, de igénye megmarad. A szülök támogatásával (gyerekfelügyelet) hamarosan újra lehetösége nyílik az utazásra: ekkor nem az együtt utazás, hanem a barátok felkeresése (rokon és barátlátogatás) a jellemző. Ez élete egyik kiemelkedő kalandját, egy afrikai utat tesz lehetövé számára. Az utóbbi években, a család anyagi helyzetének javulásával és a családi kapcsolatrendszer konszolidációjával rendszeressé válnak utazásszervezők által szervezett nyaralások. A szervezett külföldi utak a közös családi (szülö, gyerekek, testvér családja) együttlét mellett kapcsolatépítö szerepet is betöltenek, minden alkalommal új barátokat is hoznak. Barátait évente többször meglátogatja, a hangsúly ilyenkor a kikapcsolódáson és a közös szórakozáson van, mindennemü előzetes szervezés nélkül. Havonta vagy gyakrabban jár el gyerekeivel egynapos kirándulásokra a környékbeli városokba spontán ötletként, pl. egy fagylalt, vagy egy mozi az utazás célja. Az utazásokon való részvétel elsősorban anyagi helyzetétöl függ: „ebben az örületes felelötlenségben nem tudok változni. Ha van pénzem, megyek mindenfelé. Aztán meg sehová, ha elfogyott”. Ezt az esetlegességet tompítja, hogy családja a közös nyaralásoknál szükség esetén kisegíti, akár pénzzel, akár az utazáshoz autó biztosításával. Összességében tehát a turizmus számára egyszerre a megszokott környezet élményvilágából való kilépés és a kapcsolatápolás természetes közege is.

A mobilitás szervezésében az individualitás és a spontaneitás jellemzi. Utazásai során a tömegközlekedés mint kényszerüség jelenik meg: nem azért használja, mert együtt akar utazni valakikkel, hanem azért, mert mindenképpen el akar jutni valahová. Amikor anyagi vagy társadalmi erőforrásai lehetővé teszik, autóval utazik: ez egyszerre jelenti egy vágyott és részben megvalósított státusz szimbólumát és a mobilitás adta szabadság élvezetét. Elmenni valahová: tér- és időfelfogására a tér, mint fontos helyek sorozatának megélése jellemző, az ezekre irányuló mobilitásnak tulajdonít jelentőséget. Erőfeszítéseket tesz e helyek folyamatos, vissza-visszatérően való megélésére, az e helyeken létrejött kapcsolatai fenntartására, de ebben sok az esetleges, spontán döntés és a külső kényszer is. Mobilitási szándéka így nem valódi motilitás, 
inkább az esetleges lehetôségekre reagál, pontos és tudatos célkitüzés nélkül. Sokszor azonban a strukturális kényszerek, az életszférák földrajzi helyek közötti szétesése, a kényszerủségből vállalt pluri-lokális életmód mozgatja a helyek között. Időbeliségében az egyes helyek önálló szakaszokként jelennek meg, melyek között nincs szerves kapcsolat. Mivel egész életét jellemzi a keresés, a turizmus nem emelkedik ki a másság élményével. A mobilitás így számára a múlandóság és veszteség élményét is hordozza.

\section{Regressziv}

K.A. lelkész, jelenleg egy vidéki városban lakik. Hétköznapi mobilitásában hivatásának gyakorlása és a magánszféra is jelentős szerepet játszik. E két életszféra mind a földrajzi, mind a társadalmi térben átfedésben van egymással. Lelkészi szolgálatához kapcsolódó heti rendszerességü tevékenységek hasonló mobilitási mintát eredményeznek: ebben gyülekezeteinek templomai és intézményei a fó célpontok. A magánéletben ezzel szemben a mobilitás időbeli mintáját a napi rutinfeladatok határozzák meg: a gyerekek óvodája, a bevásárlás. A rendszeres mobilitáson kívül a város és környezete számos pontja jelenik meg eseti célpontként: temetések, családi találkozók, barátok felkeresése, valamint családjával közös séták és kirándulások során „fogyasztja” tágabb környezetének terét. Kiterjedt kapcsolatrendszerének és intenzív mobilitásának köszönhetően otthonosan mozog e tágabb térben, annak egészét megszokott környezetének tekinti. Otthonként azonban csak e kettős mobilitási minta közös centrumára, a parókiára tekint. Ezt elsősorban az otthon érzelmi tartalmával magyarázza: rutin tevékenységei, családi kapcsolatai és a lakás tárgyi környezete is erósíti itt az idetartozás-érzést. Mindazonáltal nincsen sem éles határ, sem pedig kontraszt az otthon és a megszokott környezet rendszeresen bejárt terei között. A hétköznapi tevékenységek e két térben keverten, határokon átnyúlóan vannak jelen. Hivatása és múltbeli gyakori költözései miatt azonban kapcsolatrendszere még e tágabb megszokott környezetből is kinyúlik. A földrajzilag távol levő rokonok, barátok érzelmi és társadalmi értelemben nem feltétlenül távoliak: közöttük többen vannak, akikkel akár napi rendszerességgel tartja a kapcsolatot. Ezt az Internet mellett munkahelye belsó mobilhálózata is lehetővé teszi: ebben kollégái mellett családtagjaival és több barátjával is ingyenesen beszélhet. A virtuális mobilitás az, ami életében a földrajzi és társadalmi tér különválását lehetővé teszi: erős kapcsolatai lakóhelyén túlra is kiterjednek.

Mobilitásában heti rendszerességgel fordul elö e megszokott környezetből történő kilépés, elutazás. Ennek célpontjai, bár a térben nem tartoznak a rutinszerủen felkeresett helyszínek közé, mégsem különlegesek a szó turisztikai értelmében. Egyfelöl ide sorolhatjuk az otthon térben elkülönülỏ szegmenseit: szülei felvidéki és anyósa dunántúli otthonát. Mindkettö életének színtere, szüken vett otthona volt egy-egy korábbi életszakaszában. Az ide történó elutazás egyfajta hazatérés: a kötődés a felkeresett családtagokhoz és a tárgyi hely otthonossága együttesen eredményezi ezt. Ahogy az otthon-fogalom is térben szegmentáltan jelenik meg nála, úgy a 
tágabb megszokott környezet is hasonló jegyeket mutat. Egyháza budapesti központja és néhány nagyobb budapesti bevásárlóközpont és áruház meglátogatása visszatérően elöfordul. Ezek az utazások nem jelentenek különlegességet életében, tartalmilag hétköznapi tevékenységeihez sorolja öket, még ha gyakoriságuk nem is mérhetö más, rutinszerü tevékenységekhez. Mind a szükebben vett otthonra, mind a tágabban értelmezett megszokott környezetre igaz, hogy a földrajzilag elkülönülö szegmenseket a múltbeli tapasztalatok és a jelenbeli virtuális mobilitás már tárgyalt eszközei integrálják a megszokott környezetbe. E két tényezö és nem a földrajzi távolság az, ami a turizmus helyett a hétköznapi élethez sorolja öket.

A térbeni mozgás mintái itt valójában ,,ráerősítenek” társadalmi terének ezen elemeire: a virtuális és tényleges mobilitás együttesen adja meg e helyek pozícióját életében. Ennek a komplexitásnak a gyökerei korábbi életszakaszának mobilitásához nyúlnak vissza: ezt egyrészt a sokféle hatás jellemzi, másrészt pedig ez nagyfokú változatosságot eredményez. Az egyik fontos tényező természetesen a tágabb család szerkezete és szokásai, illetve az ezekböl adódó mobilitás. A család más településeken élö tagjainak - nagyszülök, unokatestvérek - felkeresése legalább havi rendszerességü. A határhoz közel élö szlovákiai magyar családként a magyarországi látogatások szintén a rutin utazások közé tartoznak - bevásárlási és kulturális céllal. A mobilitás másik dimenzióját intézményei kötődései adják: a sportklub, az énekkar, édesapjának vadásztársasága. Ezek napi-heti programjai, valamint a barátokkal szervezett programok helyben is a kisvároson belüli intenzív mozgást eredményeznek. Ezenkívül az intézményekkel távolabbra is kimozdult: nem csak Szlovákia jelentős részét járta be, de Közép-Európa más országait is. E kapcsolatok révén alakulnak ki azok az attitüdök - a mobilitás az élet alapvető szervezési módja - és kompetenciák országok, városok, utazási módok, közlekedési rendszerek ismerete -, amelyek lehetỏvé teszik számára mai mobil életvitelét. Ezek az attitűdök és kompetenciák a középiskolás évek után is jelentősen tágítják az elérhető alternativák körét és hivatásában való elmélyedést: magyarországi továbbtanulással, amerikai részképzéssel, a Kárpát-medence számos helyszínén tett gyakorlattal. Ezek a helyszínek kapcsolatrendszerében ma is élnek: a térbeli távolság ellenére sikerrel igyekszik fontos kapcsolatainak megóvására.

A turizmus ebben a mintában legtöbbször nem válik el élesen a mobilitás más formáitól vagy akár a hétköznapinak tekintett élettöl. Utazásai általában több célt szolgálnak, nehezen lehetne azokat valamely turisztikai termékbe egyértelmüen beszorítani. Az utazások célpontjait tekintve többségben vannak a rokonok, barátok lakóhelyei vagy a közösségi helyszínek, mint egyháza nyaralója. Ezeken a helyszíneken egyszerre van jelen a pihenés és a kapcsolatápolás. A turizmus egyértelmüen eszköz számára élete alakítására.

Mobilitásának szervezésében ma már egyértelmủen az individuális megoldások játsszák a föszerepet. Szinte kizárólag autóval közlekedik, de ennek ellenére a tömegközlekedéssel kapcsolatban sincsenek ellenérzései: több életszakaszában gond nélkül szervezte ilyen módon akkor is bonyolult és egyedi mobilitását. Összességében mobilitására a nagyfokú tudatosság jellemző: a térbeni mozgást életének, lehetőségeinek, 
társadalmi terének tágítására használja fel. Mobilitásával aktívan alakítja mind megszokott környezetének földrajzi térbeni határait és struktúráját, mind tágabb társadalmi terét. A mobilitás adja meg többszörös és pluri-lokális társadalmi beágyazottságának lehetőségét.

\section{Eredmények}

\section{Mobilitási dimenziók közötti kölcsönhatás}

A mobilitás Kaufmann (2004) által meghatározott tényezöi közül a kompetenciák és a megfelelés személyes képességekként jelentkeznek. A turizmus esetében a kompetencia fogalmát két további tényezőre bonthatjuk tovább: az utazási szándék alakulására és az utazással kapcsolatos technikai tudásra. Ezek a képességek a gyakorlatban a technológiailag és társadalmilag meghatározott, térben és időben megszervezett mobilitási szakértői rendszerre, vagyis a hozzáférésre vonatkoztatva értelmezhetők. Az élettörténetekböl kiderül, hogy az egyéni mobilitási minta és a mögötte meghúzódó kompetencia és attitüd időben jelentős fejlődést mutatnak. E mögött a mobilitás különböző dimenziói (hétköznapi mobilitás, migráció, turizmus) közötti kölcsönhatások húzódnak meg: ezek a dimenziók kölcsönösen hatnak egymásra, az egyik dimenzióban szerzett tapasztalatok a többi dimenzióban tanúsított viselkedésre is hatást gyakorolnak. Az egyéni turisztikai élettörténet dinamikájának a megragadásához ezért bevezetjük a mobilizáció fogalmát, amelyet az egyén térbeni mobilitására gyakorolt hatásként fogunk értelmezni. A fenti életutakban a mobilizáció következő mechanizmusai bomlanak ki:

a) a mobilitás hiánya kompetenciahiányhoz vezet

A beágyazott esetben az egész életpályán végighúzódó, a megszokott környezet terére korlátozódó mobilitás mind az utazási szándék, mind pedig az utazási tudás felhalmozódásának gátja. Ezek hiányában, bár a környezet hatására sor kerül turistautakra (szakszervezeti üdülés, kórusfellépés), nem jelenik meg sem az önálló utazási döntés, sem az önálló szervezés. Ebben az esetben a földrajzi tér - hangsúlyozottan átmeneti és kényszerü - kibővülése nem érinti a társadalmi tér szerkezetét, kiterjedését. Ennek okát elsősorban abban láthatjuk, hogy a megszokott környezetből kilépő mobilitás nem jár sem az utazási kompetencia bővülésével, sem a kapcsolatháló megváltozásával.

b) a hétköznapi mobilitás bövülése felkelti a turisztikai érdeklödést (a hétköznapi mobilitás mobilizál)

A kontingens esetben az iskola- és munkahelyváltásokhoz kapcsolódó hétköznapi mobilitás és a migráció változó interakciós szerkezetet és kapcsolathálót jelez. A társadalmi tér változása képződik le a földrajzi tér használatában: a mobilitás különböző formái - így a turizmus egy része is - a korábbi mobilitási cselekmények eredményeként kialakult szokások és ismeretségek fenntartására tett kísérletként jelennek meg. A mobilitás intenzitása így elsősorban az utazási szándékra hat, melytől elmarad 
a szervezési kompetencia: a közvetlen és rövid távú rokon- és barátlátogatásokon kívül (vagyis amikor kilép a megszokott környezet társadalmi teréböl) minden nyaralás szervezését külső szakemberre bízza.

c) a turizmus hatással van a hétköznapi mobilitásra (a turizmus mobilizál)

Közvetlen hatásként a kontingens és a regresszív esetekben is láthatjuk, hogy a turizmus során kialakult új kapcsolatok fenntartására irányul a későbbi hétköznapi mobilitás. Mélyebb szinten a turisztikai élmények a hétköznapi életben is a változatosság keresést motiválják - és ennek eszközeként a hétköznapi mobilitás bővülését eredményezik. A turizmus így ebben az esetben áttételesen a hétköznapi élet terének bővülésére és átstrukturálódására is hatást gyakorol.

d) a mobilitás minden dimenziójában együttesen van változás

A regresszív esetben a mobilitás különbözö formái az egész életút folyamán, egymással párhuzamosan, nagy változatossággal jelen vannak. Ez egyrészt a megszokott környezet folyamatos kitágulásához vezet, mind a hétköznapi interakciók, mind a személyes kapesolatháló vonatkozásában, mind a földrajzi tér használatának folyamatosan változó mintái révén. E változások egymással kölcsönhatásban zajlanak le, váltakozva a térhasználat bỏvülése nyit meg új kapcsolatokat és cselekvéseket, majd a társadalmi tér megváltozása, új tevékenységek és/vagy ismerősök hatására látogat meg új helyeket. Esetében a mobilitási élmények komplexitása rendkívül változatos utazási szándékok (síelés, családi nyaralás, kerékpártúra, egyházi találkozók, hegymászás, továbbképzések, családlátogatás) mellett a szervezési ismeretek generalizálódásában is jelentkezik. Képes szakértői segítség nélkül megszervezni bármilyen utazást, megszokott környezetének társadalmi terén kívülre is.

\section{A mobilizáció formái}

A turisztikai szakirodalom a keresleti döntést három, az utazó szintjén értelmezett tényezővel magyarázza (Mill-Morrison 1985; Lengyel 1992; Formádi-Mayer 2002). Az utazási szándék (motiváció) az a tényező, amely a döntést megalapozza, míg az utazó rendelkezésére álló szabadidő és jövedelem olyan korlátozó tényezők, amelyek az érdeklődésre számot tartó utazások elméletileg végtelen elemszámú halmazát néhány konkrét utazásra szükítik le. Ezt a modellt az élettörténetek dinamikájába helyezve azt láthatjuk, hogy a korábbi mobilitási tapasztalatok határozzák meg az aktuális utazási szándékokat. Ez utóbbit nevezhetjük individuális mobilizációnak is. Mindazonáltal empirikusan a vizsgált élettörténetekben az egyéni döntésen túlmutatóan a mobilizáció további két formáját azonosithatjuk: a kollektív és az intézményesült mobilizációt.

a) az individuális mobilizáció

Az utazási élettörténetet vizsgálva egyértelmü, hogy a korábbi mobilitási tapasztalatok motiválják az utazási döntések jelentös részét. Az utazási motivációk fejlődésének elméletei ezt a hatást fejlődésként írják le (Pearce 1982; Ryan 1998). A vizs- 
gált eseteknél azonban az elméleti feltevésekkel szemben, a korábbi tapasztalatok nem jelentenek feltétlenül fejlődést: a gyerekkori szocializáció az elfogadott státusszimbólumokon (a kontingens eset tengerparti nyaralásai) vagy az önképen (regresszív eset kulturális és természeti túrái) keresztül rutinszerüen is rögzitheti az utazási szokásokat.

Az utazási tudás esetében a tapasztalatszerzés következménye az utazás megszervezésének képessége, vagyis a turizmus szakértói rendszerétöl való függetlenedés. A vizsgált esetek közül a regresszív típus az, amelynél ezt láthatjuk: az utazások szervezését maga végzi el, a kockázatokat átlátja és képes kezelni.

\section{b) a kollektiv mobilizáció}

Az utazási szándékok alakulásának második mechanizmusa a személyes kapcsolatok révén történő mobilizáció. Itt kétféle hatást figyelhetünk meg: az utazási szándékok megfeleltetését és a kapcsolatháló fenntartásának és változásának szándékát. A jelentős mások (család, barátok) utazási célokra (desztinációkra) és formákra (turisztikai termékekre) vonatkozó javaslatait a velük közös program lehetősége miatt fogadja el az egyén. A részvétel azonban olyan utazási tapasztalathoz juttatja, amely korábbi élményeiböl, késztetéseiből nem következett volna, de amely a későbbi döntéseire hatást gyakorol (újbóli utazás, továbblépés az adott termék fogyasztásában). A kollektív tapasztalatszerzés másik formája a kapcsolattartás és épités igényéből származik, és mint ilyen elsősorban a mobilitási élettörténet migrációs dimenziójával van összefüggésben. A vizsgált eseteknél ez a hatás megfigyelhetó mindhárom típusnál. $\mathrm{A}$ beágyazott típusnál ez magában az utazás tényében jelenik meg, a kontingens típusnál a kapcsolatháló fenntartása, míg a regresszív típus esetében mind a kapcsolatháló fenntartása, mind a javasolt új utazásokon való részvétel megfigyelhetö.

A kollektív tapasztalatszerzés az utazási tudásra is hatást gyakorol, amennyiben a tapasztalt útitársak, illetve a kollektív szervezés az egyéni kompetenciákat helyettesíti, az így létrejött utazás ugyanakkor fejleszti azokat. Ennek révén az egyén olyan utakra is vállalkozik, amelyeket saját kompetenciája alapján nem vállalna.

\section{c) az intézményesült mobilizáció}

Az intézményi beágyazottság említése ezen a helyen látszólag ellentmond a turizmus individualizációját kimondó modelleknek és elméleteknek (Urry 1995; Prebensen et al. 2003). Empirikusan azonban az élettörténeteket vizsgálva számos ponton látható, hogy a mobilitási tapasztalat csak egy nem szándékolt következménye valamilyen intézményi tagságnak. Ezek a tagságok nem a mobilitási lehetőségek kihasználása céljából jönnek létre, hanem az adott szervezet müködésébe való bekapcsolódás szándékával (kórus, sportklub stb.). Ezekben az esetekben az intézmények mobilitása válik az egyéni mobilitás forrásává, és gyakorol ugyanakkor mobilizáló hatást is. Mint minden utazás, az ilyen intézményi szervezésü, konkrét szervezeti céllal létrejövő utazások is tapasztalatokat biztositanak, igényeket ébresztenek. A beágyazott típusnál ez is az utazás tényében és egyben változatosságában jelenik meg, a kontingens típusnál az intézményi hatás a hivatásturizmus elkülönülő 
szegmensében jelenik meg és a szabadidős utakra kevés hatást gyakorol, a regreszszív típusnál viszont a sokrétü intézményi beágyazottság egyértelmủ szerepet játszik a komplex mobilitási minta kialakulásában (1. táblázat).

Az utazási tudás vonatkozásában hasonló hatást figyelhetünk meg, mint a kollektív tapasztalatnál: a szervezés és kockázatkezelés terén biztonságos körülmények között lehet tapasztalatokat szerezni, a kompetenciákat fejleszteni.

\section{TÁBLÁZAT}

A turisztikai mobilitás fejlödésének mintái

(Patterns of Tourism Mobility Development)

\begin{tabular}{|c|c|c|c|}
\hline \multirow{2}{*}{$\begin{array}{l}\text { A mobilizáció } \\
\text { beágyazottsága }\end{array}$} & \multicolumn{3}{|c|}{ A turisztikai mobilitás fejlödése } \\
\hline & beágyazott típus & $\begin{array}{l}\text { kontingens } \\
\text { tipus }\end{array}$ & regressziv tipus \\
\hline Individuális & - & $\begin{array}{l}\text { a gyerekkori } \\
\text { nyaralások } \\
\text { élménye- } \\
\text { nyaralni kell }\end{array}$ & $\begin{array}{l}\text { a (gyerekkori) mo- } \\
\text { bilitás élménye - } \\
\text { az utazás gazdagit- } \\
\text { ja az életet }\end{array}$ \\
\hline Kapcsolathálózati & $\begin{array}{l}\text { minimális: rövid } \\
\text { utak, termékbe- } \\
\text { mutatók a szom- } \\
\text { szédság hatására }\end{array}$ & $\begin{array}{l}\text { felkeresi életé- } \\
\text { nek korábbi } \\
\text { helyszíneit }\end{array}$ & $\begin{array}{l}\text { széles körü: új uta- } \\
\text { zási formák a bará- } \\
\text { tok kezdeményezé- } \\
\text { sére (pl. síelés, } \\
\text { hegymászás) }\end{array}$ \\
\hline Intézményi & $\begin{array}{l}\text { kényszerü: az } \\
\text { intézmények, } \\
\text { amelyeknek a } \\
\text { tagjai, ,viszik el” } \\
\text { utazni }\end{array}$ & $\begin{array}{l}\text { a munkahelyi } \\
\text { mobilitás nem } \\
\text { gyakorol hatást } \\
\text { a turisztikai } \\
\text { választásokra }\end{array}$ & $\begin{array}{l}\text { sokféle: az intéz- } \\
\text { mények, amelyek- } \\
\text { nek a tagjai, tanít- } \\
\text { ják meg utazni }\end{array}$ \\
\hline
\end{tabular}

Forrás: Saját szerkesztés.

\section{Irodalom}

Albrow, M. (1996) The Global Age. State and Society Beyond Modernity. Stanford University Press, Stanford.

Appadurai, A. (1990) Disjuncture and Difference in the Global Cultural Economy. - Theory, Culture and Society. 295-310.

Beck, U. (1986) Risikogesellschaft. Suhrkamp, Frankfurt a.M.

Beck, U. (2004) Der Kosmopolitische Blick oder: Krieg ist Frieden. Suhrkamp, Frankfurt a.M.

Bojanic, D.C. (1992) A Look at Modernized Family Life Cycle and Overseas Travel. - Journal of Travel and Tourism Marketing. 1.61-79. o.

Bonß, W.-Kesselring, S. (2001) Mobilität am Übergang vom Ersten zur Zweiten Moderne. - Beck, U. Bonß, W. (Hrsg.) Die Modernisierung der Moderne. Suhrkamp, Frankfurt a.M. 177-190. o.

Correira, A.-Santos, C.M.-Barros, C.P. (2007) Tourism in Latin America. A Choice Analysis. - Annals of Tourism Research. 3.610-629. o.

Formádi -Mayer P. (2002) Bevezetés a turizmusba tórsadalomtudományi megközelítésben. Kézirat. Veszprémi Egyetem, Veszprém.

Gregory, D.-Urry, J. (1985) Social Relations and Spatial Structures. Palgrave Macmillan, London.

Junge, M. (2002) Individualisierung. Campus, Frankfurt a. M. 
Kaufmann, V. (2004) Motility: a Key Notion to Analyse the Social Structure of Second Modernity? Bonß, W.-Kesselring, S.-Vogl, G. (eds.) Mobility and the Cosmopolitan Perspective. Workshop at the Munich Reflexive Modernization Research Centre (SFB 536) München. 75-82. o. www.cosmobilities.net

Keupp, H.-Höfer, R.-Jain, A.-Kraus, W.-Strauss, F. (2001) Soziale Landschaften in der reflexiven Moderne - Individualisierung posttraditionale Ligaturen. - Beck, U.-Bonß, W. (eds.) Die Modernisierung der Moderne. Suhrkamp, Frankfurt am Main. 160-176. o.

Kohli, M. (1989) Institutionalisierung und Individualisierung der Erwerbsbiographie. Aktuelle Veränderungstendenzen und ihre Folgen. - Brock, D.--Leu, H.R.-Preiß, Ch. (Hrsg.) Subjektivität im gesellschaftlichen Wandel. Deutches Jugendinstitut/Juventa, München. 249-278. o.

Lash, S.-Urry, J. (1994) Economies of Signs and Space. Sage, London.

Lengyel, M. (1992) A turizmus általános elmélete. KIT, Budapest.

Löw, M. (2001) Raumsoziologie. Suhrkamp, Frankfurt am Main.

Mayer P.-Pénzes E. (2007) A szolgáltató vidék. Elsö turizmusföldrajzi szimpózium. MTA Földrajztudományi Kutató Intézet, Budapest.

Mill, R.C. -Morrison, A.M. (1985) The Tourism System: An introductory text. Englewood Cliffs, Prentice Hall. Opperman, M. (1995) Travel Life Cycle. - Annals of Tourism Research. 3. 535-552. o.

Osterland, M. (1990) "Normalbiographie" und "Normalarbeitsverhältnis". - Berger, P.A.-Hradil, S. (Hrsg.) Lebenslagen, Lebensläufe, Lebensstile. Soziale Welt. Sonderheft 7., Göttingen. 351-361. o.

Pearce, P.L. (1982) Perceived Changes in Holday Destinations. - Annals of Tourism Research. 1. 145-164. o. Pearce, P.L. (1988)] The Ulysses Factor: Evaluating Visitors in Tourist Settings. Springer Verlag, New York.

Prebensen, N.-Svein, L.-Abelsen, B. (2003) I am not a Typical Tourist: German Tourists' SelfPerception, Activities and Motivations. - Journal of Travel Research. 4. 416-420. o.

Pries. L. (1998) Transnationale soziale Räume. - Beck, U. (ed.) Perspektiven der Weltgesellschaft. Suhrkamp, Frankfurt am Main. 55-86. o.

Rapoport, R.-Rapoport, R.N. (1975) Leisure and the Family Life Cycle. Routledge-Kegan Paul, London. Ryan, C. (1998) The Travel Carreer Ladder. An Appraisal. - Annals of Tourism Research. 4. 936-957. o. Towner, J. (1985) The Grand Tour. A Key Phase in the History of Tourism. - Annals of Tourism Research. 12.297-333, o.

Urry, J. (1995) Consuming Places. Routledge, London.

Urry, J. (2000) Sociology Beyond Societies: Mobilities for the Twenty-First Century. Routledge, London. Vogl, G. (2005) Mobilizing the Net. Workshop at the Wissenschaftszentrum Berlin, 13-14 October. www.cosmobilities.net

Zimmermann, C.A. (1982) The Life Cycle as a Tool for Travel Research. -Transportation. 1. 51-69. o.

\section{MOBILIZATION: ANALYSIS OF MOBILITY BIOGRAPHIES}

\section{PÉTER MAYER}

This study develops an analysis of the relationship between mobility biography and actual mobility patterns. Based on the qualitative analysis of mobility biographies three idealtypes have been developed, representing the distinct personal mobility development patterns. With unfolding the term 'mobilization' the study provides insight into the interaction between migration, everyday mobility and tourism, as well as provides and analytic tool to capture mobility change patterns. Furthermore, it is argued that travel behaviour can not be explained on the basis of individual decisions only, but it is also influenced by the individual's social ties and institutional embeddedness. 